\title{
Peranan Gemblak Dalam Kehidupan Sosial Tokoh Warok Ponorogo
}

\author{
Andri Dwi Wahyu Wiranata1, Abraham Nurcahyo² \\ ${ }^{1}$ Alumni Mahasiswa Program Studi Pendidikan Sejarah FKIP Universitas PGRI Madiun \\ ${ }^{2}$ Dosen Program Studi Pendidikan Sejarah FKIP Universitas PGRI Madiun
}

\begin{abstract}
Abstrak
Penelitian ini bertujuan untuk mengetahui sejarah perkembangan Gemblak di Kabupaten Ponorogo dan untuk menganalisis dan mendiskripsikan peranan Gemblak dalam kehidupan sosial tokoh Warok Ponorogo.

Penelitian ini menggunakan metode kualitatif. Tempat penelitian dilaksankan di Kabupaten Ponorogo mulai bulan Mei sampai Juni 2017.objek penelitian adalah peranan Gemblak dibalik kehidupan sosial tokoh Warok Ponorogo.Subyek penelitian yaitu pelaku sejarah, seniman daerah, serta narasumber rujukan dari Dinas Kebudayaan, Pariwisata, Pemuda dan Olahraga Kabupaten Ponorogo dan Pengurus PERPUSDA Kabupaten Ponorogo. Pengumpulan data menggunakan tiga macam, yaitu: observasi, dokumentasi, dan wawancara dengan teknik purposive sampling. Teknik keabsahan data menggunakan triangulasi data.

Hasil penelitian menunjukkan bahwa tradisi mengasuh Gemblak sudah berkembang lama di Kabupaten Ponorogo, bahkan diperkirakan sejak berdirinya Kabupaten Ponorogo tradisi ini sudah berlangsung di lingkungan masyarakat Kabupaten Ponorogo.Penelitian ini juga menunjukkan peranan Gemblak sangat penting di dibalik kehidupan sosial tokoh Warok Ponorogo.Peranan Gemblak sebagai pendamping Warok yang setia menemani dan menyiapkan segala kebutuhan yang diperlukan Warok dalam segala bentuk aktivitanya. Gemblak juga bisa di ibaratkan seperti istri Warok, sebab peranannya yang menggantikan sosok wanita dalam kehidupan Warok Ponorogo. Sebagai asuh yang dipelihara oleh Warok, Gemblak juga berperan sebagai lambang kejayaan bagi Warok Ponorogo di lingkungan sosialnya.
\end{abstract}

Kata Kunci: Gemblak, Kehidupan Sosial, Warok

\section{Pendahuluan}

Manusia merupakan makhluk hidup ciptaan Tuhan dengan segala fungsi dan potensinya yang tunduk kepada aturan hukum alam, menglami kelahiran, purtumbuhan perkembangan, mati, dan seterusnya. Menurut pendapat Hannah Arendt (dalam Achmad, 2006:76) menunjukkan bahwa spesies manusia bukanlah sui generis dan juga tidak sepenuhnya tidak murni dikalangan bentukbetuk kehidupan di muka bumi: "manusia meniru cara dunia memisahkan keberadaan manusia dari lingkungan hewan sematamata, tetapi kehidupan itu sendiri berada di luar dari dunia tiruan ini, dan melalui kehidupan manusia tetap berhubungan dengan semua organisme hidup yang lain."

Pandangan Arendt di atas merupakan salah satu yang mendasar dalam prespektif antropologi semenjak dibangunnya pengetahuan ini. "Peniruan manusia" (human artifice) berupa kebudayaan adalah mekanisme adaptif primer dari spesies manusia. Kehidupan manusia tidak dapat terlepas dari lingkungan, baik lingkungan 
yang berupa alam maupun masyarakat di sekitarnya. Dengan lingkungan manusia berinteraksi sehingga menumbuhkan dan menghasilkan budaya, yang terdiri dari cipta, rasa dan karsa. Nilai-nilai budaya adalah jiwa dari kebudayaan dan menjadi dasar dari segenap wujud kebudayaan.Di samping nilai-nilai kebudayaan, kebudayaan diwujudkan dalam tata hidup yang merupakan kegiatan manusia yang mencerminkan nilai budaya yang didukungnya (Abraham Nurcahyo, 2013: 8).

Kabupaten Ponorogo merupakan Kabupaten yang teretak di provinsi Jawa Timur. Letak geografis Kabupaten Ponorogo sendiri diapit oleh dua gunung besar di Jawa Timur yaitu Gunung Wilis di sebelah Timur dan Gunung Lawu di sebelah barat seperti dibanyak daerah lain di Indonesia, Kabupaten Ponorogo memiliki budaya lokal yang tentunya berasal dari warisan nenek moyang dan menjadi sebuah kebanggaan bagi masyarakatnya. Salah satu budaya lokal yang sampai sekarang masih terus dilestarikan yaitu kesenian Reog Ponorogo.

Selain menyajikan tontonan yang menarik, kesenian Reog ini ternyata juga sarat akan tradisi/kebiasaan yang telah dibawa sejak jaman nenek moyang, mulai dari gerakan tari yang erotis, mabukmabukan hingga hubungan sesama jenis/homoseksual. Dalam berbagai kisah diungkapkan, seorang Warok akan menjalani tapabrata untuk mencapai kesaktian. Bukan rahasia lagi, ketika sedang mencari kesaktian, Warok melakukan ritual puasa terhadap perempuan, sehingga untuk memuaskan hasratnya, warok lebih memilih laki-laki. Biasanya laki-laki yang dipilihnya berwajah tampan. Lelaki ini yang dipersiapkan untuk menari jathil dan lebih dikenal dengan sebutan Gemblak.

Jika pada dewasa ini, masyarakat memperlihatkan kekuasaan dan kekayaannya dengan cara mengkoleksi barangbarang yang mewah, seperti emas, mobil dan barang-barang mewah lainnya. Sangat berbeda dengan Warok di Ponorogo zaman dahulu dalam memperlihatkan kekuasaan dan kekayaannya, Warok mengasuh atau memelihara Gemblak yang banyak. Karena masyarakat menganggap bawah semakin banyak Warok memelihara Gemblak, semakin tinggi tingkat kekuasaan dan kekayaan yang dimiliki oleh Warok.

Warok berlomba-lomba dalam memelihara Gemblak, bahkan sampai beradu kekuatan untuk memperebutkan seorang Gemblak idaman. Menarik bagaimana peranan Gemblak di balik kehidupan sosial tokoh Warok Ponorogo.

\section{Tinjauan Pustaka}

\section{A. Peranan}

\section{Pengertian Peranan}

Soerjono (2014:

210-211) menjelaskan, peranan (role) merupakan aspek dinamis kedudukan (status). Apabila seseorang melaksanakan hak dan kewajibannya sesuai dengan kedudukannya, dia menjalankan suatu peranan. Perbedaan 
antara kedudukan dengan peranan adalah untuk kepentingan ilmu pengetahuan. Keduanya tak dapat di pisah-pisahkan karena yang satu tergantung pada yang lain dan sebaliknya.

Sejalan pendapat di atas, achmad (2005:157) mengemukakan bahwa dalam prespektif struktural-fungsionalis, setiap individu menempati suatu status dalam berbagai strutur masyarakat. Status dalam hal ini bukanlah prestise dari posisi individual, melainkan posisi itu sendiri. Individu menempati suatu status juga dianggap memiliki hak-hak dan kewajibankewajiban tertentu, yang merupakan peranan dalam status tersebut.

Peranan identik dengan partisipasi yang berasal dari bahasa asing participate yang berarti peran serta atau menjadi terlibat, Britha Mikkelsen (Dalam Nur dan Abraham, 2012:29) mejelaskan partisipasi merupakan kata yang sangat sering digunakan dalam pembangunan. Istilah partisipasi mempunyai banyak ragam arti diantaranya yaitu partisipasi adalah keterlibatan masyarakat dalam pembangunan diri, kehidupan, dan lingkungan mereka. Peranan tersebut dilakukan sesuai dengan kedudukan dan statusnya di dalam masyarakat.

Peranan sosial merupakan salah satu cara individu untuk membina tingkah laku sosialnya sehingga individu yang bersangkutan makin matang dan sempurna tingkah laku sosialnya guna kelancaran kehidupannya bersama individu lain dalam keluarga, kelompok, dan masyarakat (Slamet, 2010:219).

Berdasarkan beberapa ulasan di atas, peranan merupakan sebuah arti positif yang diharapkan akan mempengaruhi sesuatu yang lain. Peran juga merupakan suatu sikap atau prilaku yang diharapkan oleh banyak orang atau sekelompok orang terhadap seseorang yang memiliki status atau kedudukan tertentu.

\section{Cakupan Peranan}

Peranan lebih banyak menunjuk pada fungsi, penyesuaian diri dan sebagai suatu proses. Levinson (Dalam Soerjono, 2014:211) membagi 3 cangkupan peranan, yaitu:

a) Peranan meliputi norma-norma yang dihubungkan dengan posisi atau tempat seseorang dalam masyarkat. Peranan dalam arti merupakan rangkaian peraturan yang membimbing seseorang dalam kehidupan kemasyarakatan.

b) Peranan merupakan konsep tentang apa yang dapat dilakukan oleh individu dalam masyarakat sebagai organisasi.

c) Peranan juga dapat dikatakan sebagai prilaku individu yang penting bagi struktur sosial masyarakat.

\section{Macam-macam Peranan Sosial}

George (dalam Slamet, 2010: 228) mengungkapkan ada beberapa macam peranan sosial individu, yaitu:

a. Ascribed social roles are assigned largely on the basis of biological and 
physiological factors and other are assigned on basis of social inheritance or expected positionin society. (Peran sosial yang dibawa ditandai sebagaian besar pada macam-macam faktor biologis dan fisiologis dan yang lain-lain ditandai pada dasar-dasar warisan sosial atau kedudukan yang diharapkan dalam masyarakat).

b. Achieved social roles are attained through one's life experience and through selection among many roles which mayb assumed. (Peranan-peranan sosial yang diperjuangkan, dicapai melalui pengalaman hidup seseorang dan melalui pemilihan di antara banyak peranan yang mungkin diterima).

c. Prescribed social role includes all the approved ways of carrying out the necessary function required of the occupant of a position. (Peranan sosial yang diberikan meliputi seluruh cara yang dibenarkan membawa fungsi yang disyaratkan penempatan kedudukan).

\section{B. Kehidupan Sosial}

Konsep sosial adalah konsep keseharian yang digunakan untuk menunjuk sesuatu yang dipahami secara umum dalam masyarakat. Sedangkan konsep sosiologis merupakan konsep yang digunakan sosiologi untuk menunjuk sesuatu dalam konteks akademik. Warih dan Debi (Dalam Jurnal Agastya, 2012: 81) mengemukakan, kata sosial secara etimologis berasal dari kata sofie dalam bahasa latin yang berarti bercocok tanam, kemudian berkembang menjadi socius yang artinya teman, kawan, berkembnag, dan mengalami perubahan lagi menjadi kata sosial artinya berteman, bersama, berserikat.

Soerjono (2014: 54) interaksi sosial merupakan kunci dari semua kehidupan sosial karena tanpa interaksi sosial, tak akan mungkin ada kehidupan bersama. Menurut Soekanto (Dalam Hermawan dan Hanif, 2014: 24) dalam masyarakat sosial yang saling berhubungan secara berlanjutan menimbulkan kehidupan sosial. Kehidupan sosial juga merupakan proses sosial.

Proses sosial adalah cara-cara berhubungan yang dilihat apabila orang perorangan dan kelomok-kelompok sosial saling bertemu dan menentukan sistem serta bentuk hubungan atau apa yang mempengaruhi pola kehidupan yang ada. Slamet (2010: 157) menjelaskan bahwa sebagai komunikasi, interaksi sosial merupakan cara individu untuk memelihara tingkah laku sosial individu sehingga tetap bertingkah laku sosial dengan individu lain. Interaksi sosial dapat meningkatkan jumlah dan kualitas tingkah laku sosial individu, makin matang dalam bertingkah laku sosial dengan individu lain di dalam situasi soial.

Dari pendapat di atas dapat disimpulkan bahwa kehidupan sosial merupakan kehidupan yang ditandai dengan adanya unsur-unsur sosial kemasyarakatan. Di dalam kehidupan sosial akan menemukan sebuah interaksi sosial 
dan proses sosial yang berlangsung dengan adanya kegiatan sosial kemasyarakatan, yang sifatnya saling membutuhkan antara satu sama lainnya.

\section{Gemblak}

\section{Pengertian Gemblak}

Menurut Purwowijoyo (1990:61) Gemblakan: warok itu pantangan, tidak bermain cinta dengan wanita. Kecuali hanya istrinya sendiri, sebab jika warok sampai tergoda wanita, hilang kesaktiannya, mopol tulangnya, lunak perutnya. Karena hal itu, untuk pengganti wanita lalu menyukai anak laki-laki yang tampan wajahnya yang disebut gemblak.

Purwowijoyo, Maryaeni (2005:102) mengemukakan Gemblak adalah seorang anak laki-laki yang ganteng, usia di bawah 15 tahun, berkulit kuning. Gemblak adalah profesi anak laki-laki yang dikencani oleh Warok. Upah Gemblak tahun 60-an adalah satu ekor sapi sebulan. Gemblak selalu mendampingi Warok karena Warok tidak boleh menikah dengan wanita.

Dari pendapat tersebut dapat disimpulkan bahwa Gemblak adalah sebutan bagi anak laki-laki yang diasuh oleh Warok Ponorogo, yang berwajah tampan dan masih berumur dibawah 15 tahun. Karena Warok memiliki pantangan untuk tidak berhubungan selayaknya suami istri dengan wanita, maka Warok mengkencani Gemblak supaya kesaktiannya tidak luntur. Dalam hal ini Warok mengasuh Gemblak merupakan sebuah tradisi yang di rasa wajar bagi masyarkat Ponorogo. Soemarto (2014: 20) memaparkan bahwa, penari jathilan yang aslinya diperankan oleh anak laki-laki, sebagai penggambaran prajurit kerajaan berkuda yang gagah. Penari jathilan ini harus di perankan oleh anak laki-laki yang berusia diantara 12-15 tahun. Penari jathilan ini adalah gemblakan yang merupakan pasangan dari warok (an). Komari (dalam soemarto, 2014: 46) menjelaskan ketika gemblak memerankan tari jathil, dia diberi properti perempuan.

Gerak tarinya pun dibuat lemah gemulai bagaikan perempuan. Secara esensiail penampilan seperti ini merupakan suatu bentuk protes kepada raja Brawijaya atas ketidak tegasan sikap dalam melaksanakan roda pemerintahan. Hartono (dalam Lisa, 2009:184) Penari kuda kepang (jathilan) adalah seorang Gemblakan, sejak dahulu kala ada rahasia mengapa pertunjukan Reog selalu baik dalam menghibur penikmatnya, itu semua karena daya tarik para penari jathil yang beranggotakan anak lelaki manis.

Gemblakan dan Warokan adalah dua tetapi satu. Keduanya tidak dapat dipisahkan, ibarat merak dengan harimau. Gemblak adalah merak, sedang Warokan adalah hitam. Perkumpulan Reog merasa penuh kebanggaan jika ia memiliki penari kuda yang tampan dan manis. Peranan para penari jathil sangat menentukan keberhasilan suatu pertunjukan. Dari berbagai penjelasan tentang penari jathil, 
menunjukkan Gemblak ialah seorang anak laki-laki yang di asuh oleh Warok yang dijadikan penari Jathil dan dijadikan sarana Warok untuk bercumbu karena Warok di larang untuk berhubungan dengan wanita supaya kesaktiannya tidak hilang. Gemblak merupakan gambaran sindiran atau protes terhadap Raja Brawijaya, yang tunduk dan mengikuti perintah istrinya.

\section{Warok}

\section{Pengetian Warok}

Hanya di Ponorogo ada istilah warok itu. Begitu juga gemblakan, di pesantren disebut mairil, warok itu berasal dari kata arab WAROI artinya pimpinan, atau bisa memimpin istilah Jawa WIRANGI, maksudnya sudah waskito. Sudah mengerti tentang kasar halusnya lahir batin. Dan kegiatan hidupnya hanya untuk memberi pertolongan kepada masyarakat, negara, karena Allah atau tanpa pamrih (Purwowijoyo, 1990: 60).

Menurut Reza dan Abraham (dalam Jurnal Agastya, 2015:74) Warok berasal dari kata wewarah. Warok ialah wong kang sugih wewarah, artinya seseorang menjadi Warok karena mampu memberi petunjuk atau pengajaran kepada orang lain tentang hidup baik. Warok digambarkan sebagai orang yang sempurna laku hidupnya, dan sampai pengendapan batin.

Jika dilihat dari sudut pandang agama islam, Amal (2013: 115) menyampaikan dalam literature sufi (mistik islam) dikenal istilah wara' yaitu menjauhkan diri dari segala sesuatu yang mengandung subhat (sesuatu yang belum diketahui hukumnya) yang menyebabkan seseorang terjerumus kepada sesuatu yang haram, wara' adalah status sosial bagi seorang yang menempuh jalan sufi, status tersebut secara berurutan, taubah, wara, zuhud, tawakal, sabar, dan kerelaan.

Dengan beberapa ulasan tersebut, disimpulkan bahwa Warok merupakan pemimpin atau panutan bagi masyarakat Ponorogo yang menjunjung tinggi nilai kebaikan. Warok dapat dijadikan panutan karena Warok memiliki wawasan yang sangat luas serta memiliki tingkat kesaktian yang tinggi, sehingga dapat memberikan pengajaran hidup untuk masyarakatnya. Pengabdiannya hanya untuk negara serta memberikan pertolongan terhadap masyarakat dengan ikhlas tanpa adanya sebuah harapan untuk diberikan balasan.

\section{Sifat-sifat Warok Ponorogo}

$$
\text { Purwowijoyo (1990: }
$$

menjabarkan, beberapa sifat warok, yaitu:

a) Berwatak satria: jujur, dan suka memberi pertolongan, selalu berdarma bhakti kepada negara dan bangsa.

b) Berwatak belas kasih kepada sesama, tetapi juga berwatak kejam kepada musuh, seperti pepatah jika lentur atau lemas dapat digunakan untuk tali, jika kaku dapat digunakan untuk pikulan.

c) Banyak ilmu dan mempunyai kesaktian. Jika di waktu aman tentram seperti tak ada gunanya. Tetapi jika terjebak mara 
bahaya dapat menyelesaikan perkara. "Nama rawe-rawe malang-malang putung" (pepatah jawa).

d) Menjadi suri tauladan dan pelindung masyarakat di desa itu dan sekitarnya. Kadang-kadang lurah saja kalah wibawa.

e) Warok sejati, jika ditantang musuhh tidak bernafsu, terlebih dahulu diberi peringatan. Jika sudah tidak dapat diperingatkan baru musuh itu dilawan semuanya mengajak bagaimana dituruti.

\section{Peranan Warok Ponorogo dalam Reog}

Menurut pendapat Amal (Dalam Jurnal Sosiologi, 2013: 114) pada zaman Wengker warok umumnya menjabat sebagai demang, pimpinan reog dan sekaligus menjadi pemain barongan. Ia disegani dan dihormati, gambaran wantah dari seluruh jiwa warok diwujudkan dalam bentuk yang berpawakan tinggi besar, berkumis, dan berjanggut panjang. Pipi dan dada tumbuh bulu hitam yang lebat, memakai pakaian yang serba hitam dengan usus-usus putih yang terikat di pinggang.

Menurut kepercayaan, seragam hitam yang dikenakan oleh para waarok mengandung makna keteguhan. Sedangkan koloran dan usus-usus yang berwarna putih panjang dan terurai ujungnya merupakan lambang kesucian budi, ilmu dan tingkah laku. Dari simbol-simbol ini akhirnya didapat pengertian bahwa manusia perlu sekali dikuatkan denga kesucian budi, ilmu an tingkah laku. Sedangkan dalam pentas pertunjukan, sosok warok lebih terlihat sebagai pengawal atau punggawa raja Klana Sewandana (bagi warok muda) atau sesepuh dan guru (bagi warok tua).

Dalam pentas reog, sosok warok muda digambarkan berlatih mengolah ilmu kanuragan, digambarkan berbadan gempal dengan bulu dada, kumis dan jambang lebat serta mata yang tajam. Sementara warok tua digambarkan sebagai pelatih atau pengawas warok muda yang digambarkan berbadan kurus, berjanggut putih panjang, dan berjalan dengan bantuan tongkat.

\section{Metode Penelitian}

Penelitian mengenai peranan Gemblak dalam kehidupan sosial tokoh Warok Ponorogo ini, dilaksanakan di Kabupaten Ponorogo. Alasan pemilihanya dikarenakan hanya di Kabupaten Ponorogo sebutan Gemblak itu berada. Serta dipilihnya tempat ini menjadi lokasi penelitian karena masih banyak pelaku serta informan yang mengetahui bagaimana peranan Gemblak kala itu, ketika tradisi ini masih berjalan di daerah Kabupaten Ponorogo. Letak Kabupaten ini sangat startegis dan mudah dijangkau bagi peneliti, jarak tempuh dari Madiun sekitar $29 \mathrm{~km}$.

Pendekatan dalam penelitian ini menggunakan pendekatan kualitatif. Pedekatan kualitatif dipilih dengan pertimbangan bahwa data yang dihasilkan adalah berupa informasi mengenai pengertian sejarah perkembangan Gemblak dan peranan Gemblak dikehidupan sosial tokoh Warok Ponorogo. Sumber data sangat 
penting dalam melakukan sebuah penelitian, dengan sumber data ini diupayakan dapat membatu dalam memecahkan sesuatu masalah dan memberikan kemudahan dalam melakukan sebuah penelitian.

Adapun sumber data yang digunakan adalah sumber data primer dan sumber data Sekunder. Dalam penelitian ini, melakukan teknik sampling purposive, yaitu telah menentukan informan yang dapat memberikan informasi secara benar, tajam, dan aktual sehingga data atau informasi yang diberikan terjamin kebenarannya. Sebab informan merupakan ahli dalam seluk-beluk kebudayaan Ponorogo khususnya dalam mengetahui peranan Gemblak dibalik kehidupan sosial tokoh Warok Ponorogo.

Teknik pengumpulan data merupakan langkah paling utama dalam penelitian yang bertujuan untuk mendapatkan data. Tanpa mengetahui teknik pengumpulan data, maka seseorang peneliti tidak akan mendapat data yang diperlukan. Metode yang digunakan untuk mengumpulkan data dalam penelitian kualitatif secara umum adalah observasi, wawancara, dan dokumentasi. Pada penelitian ini, instrumen penelitian yang paling utama adalah peneliti.

Peneliti sangat berperan penting dalam penelitian karena mulai dari tahap persiapan sampai dengan penyusunan lapora, peneliti sendirilah yang menyusun hasil penelitian, observasi lapangan, dan wawancara. Alat bantu utama yang diperlukan berupa rekaman dan pencatat untuk mempermudah dalam menyimpan dan mendokumentasikan data yang dibutuhkan. Penelitian kualitatif dalam penyusunannya lebih banyak mengandalkan data studi lapangan, observasi, dan wawancara dengan berbagai informan.

Penelitian kualitatif sering lemah kebenarannya, sehingga dimungkinkan data-data atau informasi yang diperolah kurang valid dan masih diragukan credibilitasnya. Agar data yang dikumpulkan itu dapat dipertanggung jawabkan pemeriksaan keabsahan data perlu direncanakan sejak awal. Pada penelitian ini, peneliti menggunakan teknik triangulasi untuk menguji keabsahan data.

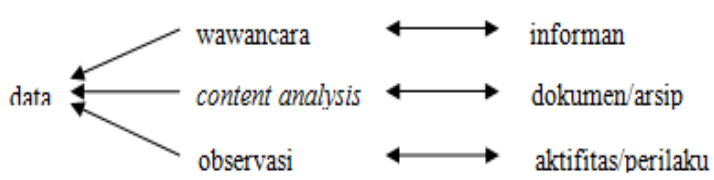

Bagan 1. Trianggulasi Sumber (dalam H.B. Sutopo, 2002: 80)

Kesimpulan dalam penelitian kualitatif adalah merupakan temuan baru yang sebelumnya belum pernah ada. Temuan dapat berupa deskripsi atau gambaran suatu objek yang sebelumnya masih remang-remang atau gelap sehingga setelah diteliti menjadi jelas, dapat berupa hubungan kausal atau interaktif, hipotesis, atau teori. Setelah adanya verifikasi maka akan di cross check sejumlah data yang terkumpul agar data yang diperoleh benar- 
benar valid, data ini berupa data temuan di lapangan ketika melakukan observasi dalam peranan Gemblak dibalik kehidupan sosial tokoh Warok Ponorogo. Pengecekan data dilakukan dengan cara membandingkan data temuan hasil wawancara, data dari hasil observasi langsung dan data temuan yang diperoleh dari dokumen.

Adapun secara garis besar proses analisis data dapat dilihat pada bagan di bawah ini :

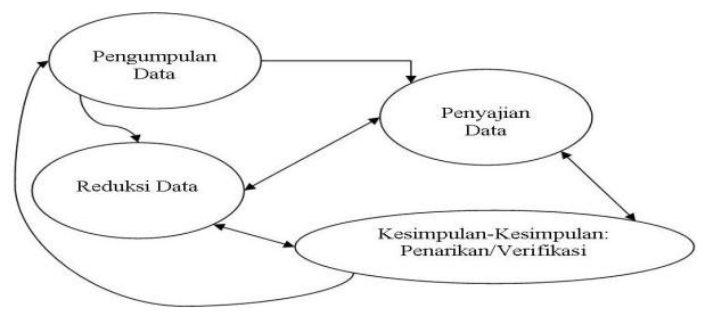

Bagan 2. analisis data model interaktif, Miles dan Huberman

(dalam Sugiyono 2012: 247)

\section{Hasil Dan Pembahasan}

\section{A. Sejarah Perkembangan Gemblak Di Kabupaten Ponorogo}

Gemblak merupakan anak laki-laki yang berusia sekitar 15 tahun yang di asuh oleh Warok. Faktor munculnya seorang Gemblak karena adanya larangan Warok untuk memiliki istri dan berhubungan dengan wanita, sehingga Warok mengambil anak asuh laki-laki yang dijadikan sebagai pendamping untuk menemani aktivitas Warok dalam setiap saat.

Gemblak muncul di Kabupaten Ponorogo diperkirakan sejak Kabupaten Ponorogo berdiri, karena dari beberapa informasi menyatakan bahwa Gemblak sudah lama adanya. Sebab Gemblakan merupakan tradisi kuno yang hanya ada di Kabupaten Ponorogo.Karena zaman dulu kurang ada minat untuk menulis pada masyarakat, tidak adanya juga prasasti yang menunjukan kepastian tahun berapa Gemblak muncul.

Ciri fisik yang dimiliki Gemblak yaitu berkulit putih, bersih dan berparas tampan. Pada umumnya Warok menyukai anak yang berparas tampan serta putih dan bersih karena enak untuk di pandang.Dengan ciri fisik yang dimiliki, maka Gemblak memiliki kepribadian yang murah senyum, lemah, lembut, sopan dan disiplin. Gemblak sangat dikenal dengan dengan kepribadiannya yang murah senyum, setiap ketemu dan bicara dengan siapa pun dia pasti akan tersenyum.

Berbanding lurus dengan kepribadiannya, dalam beraktivitas di lingkungan masyarakat Gemblak memiliki kehidupan yang sederhana dan sangat bersosial kepada masyarakat lingkungan sekitarnya. Dengan kepriba-diannya yang murah senyum Gemblak sangat di sanjung oleh msyarakat disekitarnya.Gemblak beraktivitas selayaknya anak laki-laki seusianya, tidak ada tingkatan kelas kehidupan diantara Gemblak dengan masyarakat.

Dalam sejarah perkembangan Gemblak di Kabupaten Ponorogo, pada pemilihan anak asuh atau yang biasa disebut Gemblak, dapat dikatakan bahwa 
Warok sangat selektif dalam pemilihannya. Tidak sembarang orang atau anak laki-laki bisa menjadi Gemblak. Kadang banyak pula Gemblak yang di jadikan rebutan untuk di asuh sehingga menimbulkan gesekan antar Warok di Kabupaten Ponorogo. Sampaisampai ada Warok yang rela mengorbankan nyawa nya demi memperebutkan Gemblak yang disukai olehnya. Hal ini dikarenakan Gemblak merupakan salah satu simbol kekuasaan pada zaman itu.

\section{B. Peranan Gemblak Dalam Kehidupan} Sosial Tokoh Warok Ponorogo

Kesenian Reog Ponorogo identik memiliki tokoh yang terkenal dengan gagahberani serta kesaktiannya yang melebihi masyarakat lainnya, dan biasa di panggil dengan sebutan Warok. Karena Warok dilarang memiliki istri, maka Warok mengambil anak asuh atau sering di kenal dengan Gemblak, yang di jadikan sebagai pendamping dalam berbagai aktivitasnya.

Maka dalam hal ini Warok dan Gemblak memiliki hubungan yaitu, selaku pengasuh dan anak asuh yang di ambil dari orang tunya melalui kesepakatan yang sudah di tentukan bersama. Biasanya Gemblak di asuh atau istilah lain di sewa dengan kesepakatan yang di setujui secara bersama, pada umumnya Gemblak di sewa paling lama dengan jangka waktu 2 tahun dengan imbalan seekor sapi. Warok selalu membimbing dan mengarahkan Gemblaknya, selayaknya orang tua yang tidak ingin anaknya terjerumus dalam sesuatu hal yang dilarang oleh agama dan hukum. Namun dalam saat tertentu pola komunikasi ini berubah menjadi pola komunikasi yang menyerupai hubungan antara suami dengan istri. Pola ini berlangsung di antara Warok dengan Gemblak yang telah di asuhnya. Dari sudut pandang lingkungan sosial, tokoh Warok merupakan seseorang yang terpandang.

Masyarakat juga mempercayai bahwa Warok bisa di jadikan panutan dan tuntunan yang tepat bagi mereka, sehingga kehidupan masyarakat bisa aman, nyaman, dan tentram. Sebab itulah Warok dijadikan seseorang yang di tuakan atau kata lain bisa di sebut dengan pemimpin. Ketika memimpin, Warok sangatlah tegas, adil, jujur dan bijaksana karena itu memang sifat yang dimiliki olehnya. Warok juga dikenal dengan tokoh yang bisa menyembuhkan segala penyakit yang di derita oleh masyarakatya, karena Warok memiliki kesaktian yang luar biasa.

Dalam berbagai aktivitas kehidupan sosial Warok Ponorogo akan selalu di dampingi oleh Gemblaknya, karena Gemblak berperan sebagai pendamping Warok dan memenuhi semua kebutuhan Waroknya. Peranan Gemblak dalam kehidupan sosial Warok Ponorogo sangat terlihat ketika Warok berinteraksi dengan masyarakat di kegiaatan-kegiatan lingkungan. Seperti di acara pernikahan Warok akan selalu di temani Gemblak disamping nya. Pada posisi ini Gemblak berperan sebagai asisten yang 
membawakan rokok dan keperluan yang dibutuhkan oleh waroknya. Tak jarang juga Gemblak di pinjam untuk menjadi pramusaji di acara pernikahan, yang berperan sebagai pembagi rokok, minuman, dan makanan kepada tamu yang datang di acara tersebut.

Gemblak juga sering untuk diminta menemani Warok ke pasar untuk berbelanja serta berinteraksi dengan masyarakat.Jika dalam kacamata budaya Gemblak berperan sebagai penari jathil yang ada di susunan tarian di kesenian Reog Ponorogo, maka dalam hal ini Gemblak diminta Warok untuk menemani bersosialisasi dengan orang yang berada di paguyuban Reog Ponorogo.

Setiap saat Warok akan ditemani oleh Gemblaknya, bahkan ketika malam hari juga akan menemani Waroknya untuk beristirahat. Tidak heran ketika ada Warok pasti disana juga akan ada Gemblaknya, mereka adalah dua unsur yang tidak terpisahkan. Masyarakat Ponorogo menilai hubungan Warok dan Gemblak merupakan hubungan yang wajar dan biasa saja.

Sejak berdirinya Kabupaten Ponorogo mengasuh Gemblak merupakan kebudayaan yang biasa dijalankan oleh Warok Ponorogo. Kebudayaan ini berjalan dari waktu ke waktu sehingga bisa disebut menjadi sebuah tradisi kuno yang berjalan di Kabupaten Ponorogo.

\section{Penutup}

\section{Simpulan}

Kabupaten Ponorogo dikenal dengan julukan kota Reog atau bumi Reog, karena daerah ini merupakan daerah asal dari kesenian Reog Ponorogo. Kota yang menjujung tinggi nilai-nilai kesenian dan tradisi, sehingga banyak kesenian dan tradisi yang berkembang di Kabupaten Ponorogo. Salah satunya ialah tradisi kuno yang terdapat di Kabupaten Ponorogo adalah tradisi Gemblakan. Tadisi yang mempercayai bahwa tokoh Warok Ponorogo dilarang untuk beristri, sehingga digantikan peranan istri kepada seorang anak laki-laki yang biasa di panggil dengan julukan Gemblak.

Lemah-lembut, ramah, dan murah senyum merupakan kepribadian yang dimiliki Gemblak yang membuat Warok sangat suka kepadanya. Watak yang tegas yang dimiliki Warok membuat Gemblak menjadi patuh dan menurut. Kehidupan sehari-hari Gemblak juga beraktivitas layaknya anak laki-laki seusianya, tidak ada batasan untuk Gemblak berelasi sosial dengan masyarakat. Hubungan anak asuh dan pengasuh yang muncul dalam hubungan Warok dan Gemblak membentuk pola hubungan yang orang tua dengan anaknya, yang menginginkan semua yang terbaik untuk anaknya.

Warok dikenal sebagai pemimpin di lingkungannya, sebab Warok memiliki kekuatan yang lebih dan dianggap bisa dijadikan sebuah panutan oleh masyarakatnya. Pada kehidupan sosial Warok Ponorogo, Gemblak berperan sebagai pendamping dan pelayan 
Waroknya. Dia bertugas melayani dan menyiapkan semua kebutuhan yang dibutuhkan oleh Warok, maka peranan seorang istri dalam kehidupan seorang Warok bisa digantikan oleh Gemblak .

Bahkan Warok lebih nyaman dengan seorang Gemblak dalam segala aktivitasnya daripada seorang wanita. Gemblak juga sering dipinjam untuk dijadikan pramusaji dalam acara pernikahan, yang bertugas sebagai pembagi rokok, makanan dan minuman kepada tamu yang datang dalam acara tersebut. Hubungan ini berlangsung di Kabupaten Ponorogo tanpa adanya tentangan dari masyarakat, atau dalam kata lain masyarakat Ponorogo dalam posisi ini menerima akan adanya hubungan Warok dengan Gemblak.

Tradisi Gemblakan yang ada di Kabupaten Ponorogo ini pada saat ini sudah tidak dijalankan lagi. Sebab masyarakat Ponorogo mulai berkembang dan mengenal pendidikan formal. Terlebih didorong dengan ilmu-ilmu agama yang mulai berkembang di Kabupaten Ponorogo ditandai dengan banyaknya berdiri pondokpondok pesantren, seperti Gontor, Mayak dan pondok pesantren yang lain. Sehingga masyarakat lebih bisa memilah mana tradisi yang harus dikembangkan dan tidak.

\section{Daftar Pustaka}

Abraham Nurcahyo, dkk. 2013. Ilmu Sosial Dan Budaya Dasar. Madiun: Institut Press IKIP PGRI MADIUN

Badan Pusat Statistik Kabupaten Ponorogo. 2016. Kabupaten Ponorogo Dalam
Angka 2016. Ponorogo: BPS Kabupatren Ponorogo

Hermawan Purwo Saswito dan Muhammad Hanif. Jurnal Sejarah dan Pembelajarannya. Dalam Agastya. Volume 04 Nomor 02. Juli 2014. Kehidupan Sosial Ekonomi Juru Pelihara Situs Cagar Budaya di Madiun Tahun 2013. (Hal.24). Madiun: Prodi Pendidikan Sejarah IKIP PGRI MADIUN

Lisa Sulis. Dalam Filsafat. Volume 03 Nomor 02 Oktober 2013. Perilaku Ritual Warok Ponorogo Dalam Sejarah Kesenian Reog Ponorogo (Prespektif Eksistensialisme).

(Hal.184). Yogyakarta: UGM

Maryaeni. 2005. Metode Penelitian Kebudayaan. Jakarta: Bumi Aksara

Nur Hidayati dan Abraham Nurcahyo. Agastya: Jurnal Sejarah dan Pembelajarannya. Volume 02 Nomor 01 Januari 2012. Kesadaran Sejarah dan Partisipasi Masyarakat Dalam Pelestarian Monumen Jendral Sudirman (Studi Kasus di Desa Pakis Baru Kecamatan Nawangan Kabupaten Pacitan). (Hal.29). Madiun: Prodi Pendidikan Sejarah IKIP PGRI MADIUN

Purwowijoyo. 1990. Babad Ponorogo Jilid VII Ponorogo Zaman Belanda. Ponorogo: KANDEP DIKBUD Kabupaten Ponorogo

Reza Adi Primawan dan Abraham Nurcahyo. Agastya: Jurnal Sejarah dan Pembelajarannya. Volume 05 Nomor 01 Juli 2015. Peranan Mbah Wo Kucing Dalam Pelestarian Reog dan Warok di Kabupaten Ponorogo. (Hal.74). Madiun: Prodi Pendidikan Sejarah IKIP PGRI MADIUN

Saifudin, F.A. 2005. Antropologi Kontemporer Suatu Pengantar Kritis Mengenai Paradigma. Jakarta: Kencana

Santoso, Slamet. 2010. Teori-teori Psikologi Sosial. Bandung: Rafika Aditama

Saputra, S.U. 2012. Metode Penelitian Kuantitatif, Kualitatif, dan Tindakan. Bandung: Rafika Aditama 
Silalahi, A.G. 2003. Metodologi Penelitian dan Studi Kasus. Sidoarjo: Citramedia

Soekanto, S dan Budi. 2014. Sosiologi Suatu Pengantar. Jakarta; Raja Grafindo Persada

Soemarto. 2014. Menelusuri Perjalanan Reyog Ponorogo. Ponorogo: Kotareog Media

Sudaryono, dkk. 2103. Pengembangan Instrumen Penelitian Pendidikan. Yogyakarta: Graha Ilmu

Sugiyono. 2012. Metode Penelitian Kuantitatif, Kualitataif, dan Kombinasi (Mixed Methods). Bandung: Alfa Beta

Sugiyono. 2013. Cara Mudah Menyusun Skripsi, Tesis dan Disertasi. Bandung: Alfa Beta

Sutopo, H.B .2002. metodologi Penelitian Kualitatif. Surakarta: Sebelas Maret University Press

Taufiq, Amal. Sosiologi Islam. VOL. 03. NO. 02. Oktober 2013. Perilaku Ritual Warok Ponorogo Dalam Prespektif Teori Tindakan Max Weber. (Hal. 15). Surabaya: IAIN Sunan Ampel Surabaya

Warih Yudo Sanjoyo dan Debi Setiawati. Agastya: Jurnal Sejarah dan Pembelajarannya. Volume 04 Nomor 02 Juli 2014. Perubahan Sosial Budaya Desa Purwodadi Kecamatan Barat Kabupaten Magetan Tahun 1990-2010. (Hal.81). Madiun: Prodi Pendidikan Sejarah IKIP PGRI MADIUN 